University of Nebraska - Lincoln

DigitalCommons@University of Nebraska - Lincoln

Faculty Publications from the Harold W. Manter Laboratory of Parasitology

$12-2008$

\title{
Presentation of the 2008 ASP Distinguished Service Award to William C. Campbell
}

Robin M. Overstreet

Gulf Coast Research Laboratory, robin.overstreet@usm.edu

Follow this and additional works at: https://digitalcommons.unl.edu/parasitologyfacpubs

Part of the Parasitology Commons

Overstreet, Robin M., "Presentation of the 2008 ASP Distinguished Service Award to William C. Campbell" (2008). Faculty Publications from the Harold W. Manter Laboratory of Parasitology. 432.

https://digitalcommons.unl.edu/parasitologyfacpubs/432

This Article is brought to you for free and open access by the Parasitology, Harold W. Manter Laboratory of at DigitalCommons@University of Nebraska - Lincoln. It has been accepted for inclusion in Faculty Publications from the Harold W. Manter Laboratory of Parasitology by an authorized administrator of DigitalCommons@University of Nebraska - Lincoln. 


\title{
PRESENTATION OF THE 2008 ASP DISTINGUISHED SERVICE AWARD TO WILLIAM C. CAMPBELL
}

\author{
Robin M. Overstreet \\ Chair, Distinguished Service Award and Extramural Awards Committee, Department of Coastal Sciences, The University of Southern \\ Mississippi, 703 East Beach Drive, Ocean Springs, Mississippi 39564.e-mail: robin.overstreet@usm.edu
}

The ASP Distinguished Service Award Committee, comprised of Gene Foor, Richard Clopton, Herman Eure, and me, is ecstatic that Council unanimously approved the nomination of Dr. William Campbell by Thomas Klei, with support from Roger Prichard and Robert Grieve. As expressed by Tom Klei, ASP honors itself by presenting this award to "Bill."

First, we borrowed Bill from his native Northern Ireland and Trinity College, University of Dublin, so he could pursue graduate studies at the University of Wisconsin. We then maintained him with a stint in the University of Cambridge laboratory of Lawson Soulsby (soon after created Baron Soulsby of Swaffham Prior in the U.K., with an active seat in the House of Lords) and a period of travel as a Louisiana State University Inter-American Fellow; by a hire at the Merck, Sharp \& Dohme Company for his illustrious career tenure lasting from 1957 to 1990; and now at Drew University as a Dana Fellow for scientists emeriti. He also holds adjunct professorships at New York Medical College, the University of Pennsylvania, and Drew University.

Bill represents an extremely strong nominee. Briefly, he meets all the criteria: longevity as an active ASP member as evidenced by continuous membership and regular attendance at annual meetings. Bill has been an active, loyal, enthusiastic member since 1954 as well as an active member or invited guest of the New England Association of Parasitologists (New Jersey Society for Parasitology), Helminthological Society of Washington, Parasitology Section of the Canadian Society of Zoologists, and American Society of Tropical Medicine \& Hygiene as well as other American medical societies plus international societies and commissions. He has served on 9 different ASP committees, some multiple times, and as chair on 6, as well as Vice-President in 1979, President in 1987, Member of Council in 1972-1976, and presently Consulting Editor to the Journal of Parasitology. He also has held similar positions in several of the other societies to which he belongs. He has been an active leader in the promotion of parasitology through a variety of endeavors over the years. We consider the Society to be extremely fortunate to have Bill as one of our productive members and certainly one of its most shining stars, being elected to the National Academy of Sciences in 2002. He has been successful because of his expert management skills, knowledge of financial matters, insightful analyses, intelligence, gentlemanly nature, and real spirit of scholarship. He was directly involved as head of a team at Merck Institute for Therapeutic Research with the development of 6 pharmaceutics, including Thiabendazole and Ivermectin, both of which have had a huge helpful influence on human and animal health. He has also made significant contributions in cryopreservation of parasites that remain infective, novel animal models for experimental parasitology studies, immunology, pathogenesis, and parasite recovery from tissues as well as in other fields of parasitology.

Bill's Society service probably has been most relished by those individuals and organizations that he helped. Even in "retirement," his service to the scientific community continues; he presently teaches and mentors undergraduate and graduate students at Drew University. He is continually promoting parasitology locally, regionally, nationally, and internationally. Anyone hearing one of his presentations or lectures on any subject understands that Bill is the quintessential gifted speaker and ambassador.

Of special interest is his service to millions of people in Africa, Central and South America, and Yemen who are affected by "river blindness," a disease caused by the filaria Onchocerca volvulus, which is transmitted by the bite of a black fly. He spearheaded the decision of Merck \& Company to distribute Ivermectin, branded as Mectizan, for free to millions of persons in endemic areas of the world.

I have been fortunate to collaborate with Bill on one of his many favorite topics, Antarctic exploration. Together, as a continuation of his 1987 presidential address, we put faces and personalities on many of the participants in the last and fatal Scott Expedition of 1910-1913, that had new species of worms named after them. Other ASP members, such as Bob Grieve, have been stimulated by Bill's polar studies. Bob was intrigued with the possibility that Scott and his companions died because they did not make full use of the dogs they took, perhaps because the dogs were sick and dying from heartworm.

Bill's life stretches well beyond parasitology and the Society, but he frequently drags parasites into some of these ventures such as poetry, exemplified by "Vectorial notes of a restoration poet" in Parasitology Today and his poems read during the 2008 ASP Students Symposium; drama, exemplified by the thespian Bill stealing every scene in which he played the "Old Actor" in a New Jersey Public Theatre production of The Fantasticks; and painting, exemplified by the several tapeworm trophies donated to the ASP auction that have recently attracted record bids.

With his wife of 46 years, Mary Mastin Campbell of New Jersey, beside him, we enthusiastically honor William Campbell with the 2008 Distinguished Service Award for his outstanding contributions to the Society and to the Parasitology Community in general.

Congratulations, Bill! 